\title{
Integrating the Web - A Study of Hotel Web Use
}

\author{
Audra Lukaitis \\ RMIT University, Melbourne, \\ Australia
}

Audra.Lukaitis@rmit.edu.au

\author{
Bill Davey \\ RMIT University, Melbourne, \\ Australia
}

\begin{abstract}
This study looks at web use in hotels using a set of dimensions developed by Hashim, Murphy \& Law (2007). The study investigates future directions of web use by looking at trends in one of the most established web communities. We found that the web features in the Hashim et al. dimensions model were universal across all types of hotel accommodation. We also found that directions such as disintermediation and the use of alliances did vary across the population. These differences seem to indicate the need for a richer model based on or incorporating strategic planning.
\end{abstract}

Keywords: Web site evaluation; Web site design; Web site strategy; e-Tourism; ICTs in Tourism; Hotel web sites

\section{Introduction}

Since 1963 when American Airlines introduced the first online computer reservation system (CRS) with its Semi-Automated Business Reservation Environment (SABRE), and the watershed of 1976 when the first travel agencies connected to Apollo (the CRS of United Airlines) (Maurer, 2003) the tourism industry has evolved into a complex web of partnerships and alliances, collaborating at many levels, strategically supported by ICTs at nearly every aspect of the value chain. This network of alliances supported by an advanced ICT infrastructure is instrumental to the current-web-based reservation systems that enable customers or their intermediaries to book travel, make hotel reservations and even hire a car. Few other industries rely on so many collaborators to deliver their products (Buhalis, 1998). Not surprisingly, the travel sector is rated among the top three product or service categories purchased via the Internet (Heichler, 1997; Heung, 2003; Tweeney, 1997; Yoffie, 1997).

The tourism industry is logically a great fit for use of the web. The industry must communicate with potential customers who are, by definition, remote from the venue. The main transaction takes place when money is exchanged for the information contained in a set of tickets or service, well before the product is actually experienced. At the start of the web - as a real entity available

Material published as part of this publication, either on-line or in print, is copyrighted by the Informing Science Institute.

Permission to make digital or paper copy of part or all of these works for personal or classroom use is granted without fee provided that the copies are not made or distributed for profit or commercial advantage AND that copies 1) bear this notice in full and 2) give the full citation on the first page. It is permissible to abstract these works so long as credit is given. To copy in all other cases or to republish or to post on a server or to redistribute to lists requires specific permission and payment of a fee. Contact Publisher@InformingScience.org to request redistribution permission. for business - researchers such as Gilbert (1990:664) noted, "IBM specialists have predicted that by the early 1990s central automated systems could remove the need for travel agents. Alternatively, there is little evidence that direct sell is on the increase."

As the web grew in terms of numbers of connected customers, and as a more secure communication channel for funds 
transfer, the tourism industry quickly accommodated the technology. (The introduction of Java the first programming language not dependent on a particular operating system or microprocessor - was also instrumental in transforming the web from a text and static image based medium into a more interactive multimedia channel).

In this context the role of hotel web sites and their continuing importance as part of a hotel's channel distribution strategy can be a valuable source of competitive advantage.

Interestingly, Murphy, Schegg, and Olaru (2006:161) caution

"questions about better Internet use remain, such as what Internet technologies tourism operators should adopt, how to apply these technologies to business activities, and what theories help explain and predict their successful adoption".

Now, as we move into the mature stages of the technology, companies can look to one of the earliest adopters to see what direction the web will take.

To this end, this study looks at hotel web sites using a set of dimensions developed by Hashim, Murphy, and Law (2007). This exploratory study seeks to find future directions of web use by looking at trends in one of the most established web communities.

\section{The Research Environment}

There have been two major lines of enquiry followed by researchers into web use by the hotel industry: finding what influences buyers, and finding what hotels have done with their web sites Law and Hsu (2006) remark that researchers:

"have long agreed that it is essential to have a set of specific criteria against which to assess the effectiveness of tourism and hospitality Websites".

This exploratory investigation focuses on what hotels have done with their web sites in the context of a mature tourism and hospitality industry.

We start with two major studies. Jang, Hu, \& Bai, (2006) looked for a relationship between the types of marketing in hotel web sites and the financial performance of sites. Of interest to us is the characterization of web sites used in the study, where three levels of relationship were proposed: Level 1: Basic - consists of online product information and company contact details. Level 2: Accountable - is characterized by relationship building, customer feedback, trust, company financial information and so on. Level 3: Partnership - is categorized as including "valueadd" features including loyalty programs, exclusive "hotlines", personalized accounts". There does not appear to be any substantial differentiation between Level 2 and Level 3, other than loyalty program rewards or a hotline service or offering "exclusive" services, adding value to the company-customer relationship.

The Jang et al. (2006) characterization appears in full in the following: "Table 1: Framework for e-relationship marketing through hotel websites". Three levels of relationship are detailed in the left hand column, while web site features relating to the level of relationship are itemized in the right-hand column. 
Table 1: Framework for e-relationship marketing through hotel company websites

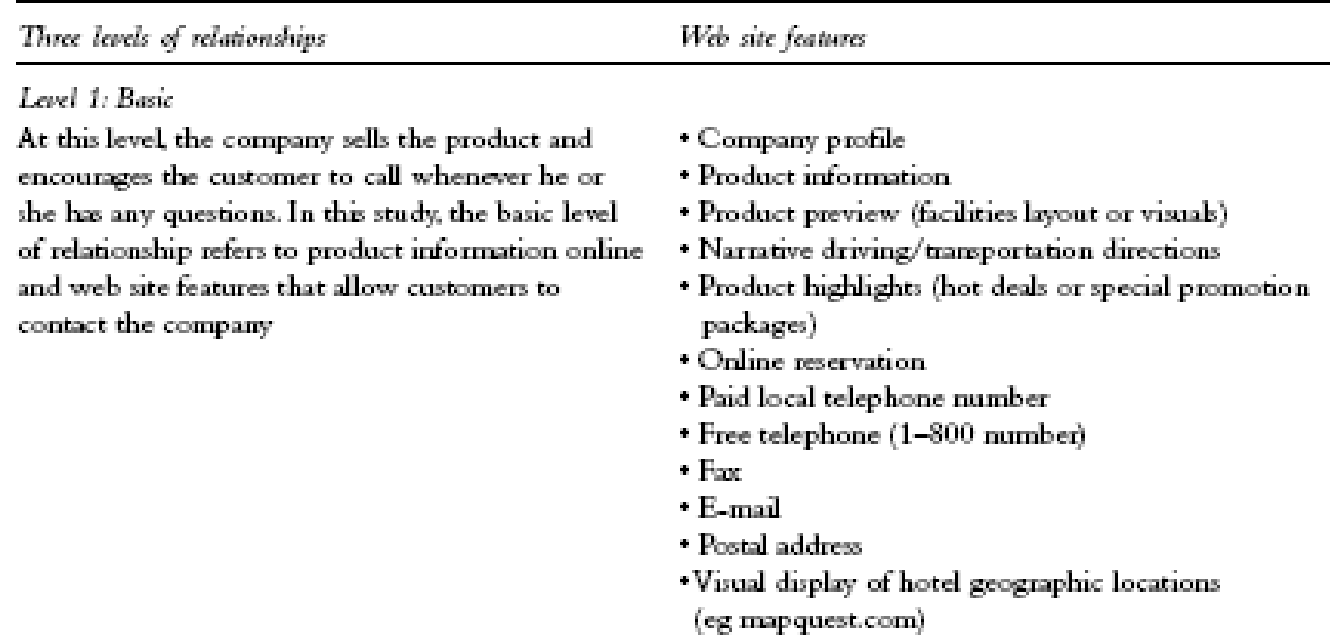

Level 2: Accowntable

At this level during and after the purchase, the company solicits from the customer any product improvement suggestions and specific disappointments and keeps in touch with the customer with suggestions about improvements that have been made or creative suggestions for future events. In this study, the proactive level of relationship refers to web site features that are meant to hold customers accountable and build deeper customer relationships
- Customer service pages (FAQ)

- Complaint handling policy (indicating how and when the complaint will be handled)

- Internet privacy policy

- Change or cancel a reservation

- Security alert

- Annual report

- Most recent financial information update

- Free sign up for product information and promotion packages

- Local search engines (a search function for within the company site)

- Feedback (encouraging customers to provide feedback)

- Chat (allowing customers to interact with each other and the site-a real time conferencing)

- Electronic bulletin board (allowing customers to share information publicly)

Level 3: Parthership

At this level the company works continucusly with customers to discover ways to deliver better value. In this study, the partnership level of relationship refers to web site features that are geared up to add value to this company-customer relationship.
- Loyalty programs (eg. frequent stry program)

- Differential membership structure

- Hotline exclusively for members

- Personalised account for members only

Similarly, a recent study by Hashim et al. (2007) looked at web design frameworks. This study proposed five dimensions of a web site, each with a number of attributes that echo the Jang et al. (2006) framework.

The five dimensions were derived from a number of previous studies, both of web designs and also studies looking at the importance of the dimensions to buyers (e.g. Law \& Hsu, 2006). In the Hashim et al. (2007) study, 74 features were consolidated into five main dimensions and $15 \mathrm{sub}$ 
dimensions. The five dimensions (in decreasing order of importance) consisted of: Information and Process, Value Added, Relationships, Trust and Design and Usability.

In contrast to the Jang et al. (2006) framework, the Hashim et al. (2007) model (See Figure 1) categorized "Trust and Design", and "Usability", as separate dimensions. Trust usefully includes security, information privacy, branding, timeliness and copyright. The attributes of Design and Usability includes the aesthetics of the web site and navigation, popularity, size and downloading time.

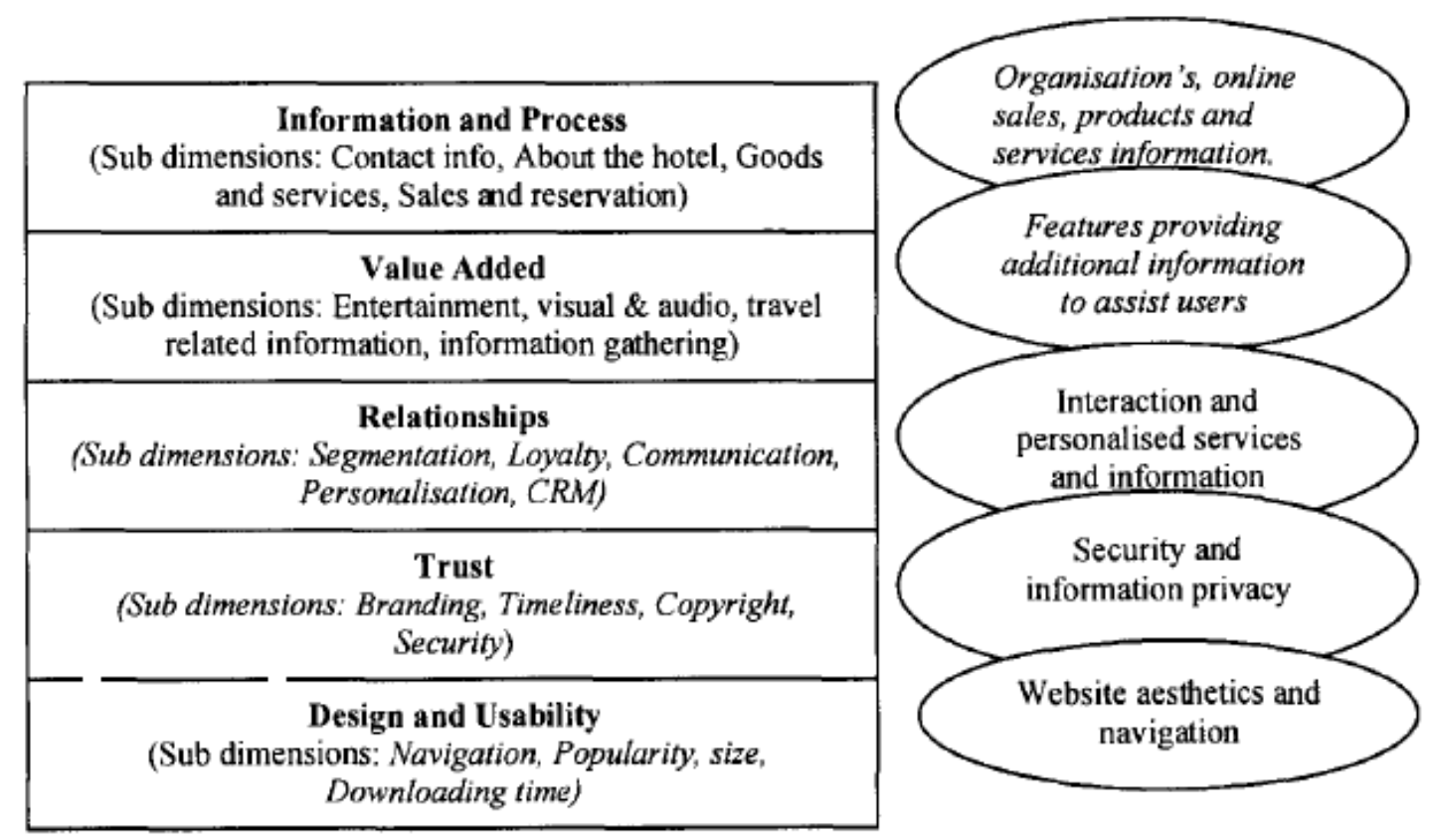

Figure 1. Dimensions of Hotel Website Quality

(From Hashim, Murphy \& Law, 2007, 22)

The Hashim et al. (2007) study found the most researched features related to the Information and Process dimension; the most important sub-dimensions consisting of: sales or reservations, contact information, sales promotions, goods and services, about the hotel. In a sense this comes as no surprise - as Sigala, Lockwood, Jones (2001) remark "hotels have always tried to sell the right room at the right price to the right customer. This is a fundamental goal which remains unchanged, whatever means are used to achieve it".

Hashim et al. (2007) concluded that further complementary research was needed in terms of scrutiny of other variables or examination of relationships between organizational characteristics such as "size and star category".

Interestingly, Murphy, Schegg and Olaru (2006) found (with limited research) into the evolution of hotel internet adoption that as "a rule, the domain name age reflects the presence of advanced website features".

Our study sought to find trends in web usage that were not described by aspects of the Hashim et al. (2007) model. Our suspicion, inspired by the strategic work of (Clarke, 2005) and Porter (2001) suggests that, with a mature integration of the web into business practice, factors of strategic importance and competitive edge should become apparent with careful study. Porter defines strategic positioning (in terms of the Internet) as "doing things differently from competitors, in a way that delivers a unique type of value to customers. This can mean offering a different set of 
features, a different array of services, or different logistical arrangements". If these strategic factors do appear in these complementary study findings, then further research would be indicated in terms of "strategic stance" or "value proposition" or strategic "alignment" as reflected via web sites.

To this end this study investigates a number of Melbourne-based hotels, applying the Hashim et al. (2007) "Dimensions of Hotel Website Quality" framework.

\section{Method}

This study sought to answer the question "Do recent models of web site categorization describe all hotel web site features or are strategic business practice issues appearing in web sites?" The most recent categorization we could find was that of Hashim et al. (2007). This model is built on several previous studies - incorporating a plethora of attributes from those studies. Since we aim to search for examples showing characteristics beyond the model it was decided to survey web sites from a single market in a big city.

Melbourne, Australia is a city covering $7,695 \mathrm{~km}^{2}$ and housing 3,684,461 people. (Melbourne City Council, 2007) The visitor bureau reports that the city contains 20,000 accommodation rooms within a $15 \mathrm{~km}$ radius of the CBD, that service an estimated international visitor population of 1.5 million in 2007, with visitors to reach 2.3 million in 2016, (Tourism Victoria, 2007), alongside a domestic market forecast to increase by $1.0 \%$ in 2007 to 54.0 million. The accommodation places are provided by a very large number of hotels and apartment buildings. Google maps provide a list of 3,810 for hotels near Melbourne. Obviously this size population requires us to make a sample of the available hotels. We did this using the star rating given by the website www.wotif.com. Star ratings have come into some disrepute of late, but it can be argued that a sample should be taken using the information available to a prospective buyer and the star system has not been replaced as yet. Once a sample, generated by a request to www.Wotif.com, was obtained, each hotel website was found and a check made to ensure that hotels from the same chain did not become represented twice.

Using the dimensions of Hashim, et al. (2007), an exploratory study was made of a range of hotel web sites in the market described above (three star and above). The choice of a single market was intended to keep static the destination and other competitive factors. Each hotel web site was assessed according to the "Hashim dimensions": Information and Process, Value Added, Relationships, Trust and Design and Usability. Each of two researchers then examined the web sites using the detailed list of characteristics in Hashim et al. (2007) and characterized each aspect of the web site according to the model. There was complete agreement between the researchers, indicating the simplistic nature of the original model. Notes were kept of aspects of the web sites that did not fit the dimensions. In the first instance an attempt was made to find any correlations between star rating and dimensions of the web site.

\section{Results}

Hotels were deliberately chosen to represent each of the market sectors as defined by price of rooms, number of hotels in chain, country of company ownership etc. Surprisingly every sector showed characteristics in all the dimensions we looked for. When an attribute was missing, such as the common practice of not giving contact names on web sites, it was missing from most sites. There was no discernable difference between the functional maturities of web sites from one level of hotel to another. In essence it can be said that any attribute in the dimensions that was seen as useful to the hotel had been included and others have been left out deliberately. This indicates that web sites have become an integral part of the operation of all hotels and penetration of this marketing and sales channel has been universal in the industry. 
The features of hotel sites that were not part of the dimensions are a much more interesting story. At the start of the web as a real entity available for business, researchers such as Gilbert (1990) predicted the demise of travel agents as providers communicating directly with consumers.

Most of the hotels surveyed showed evidence of strategic partnerships with other travel related businesses. This corresponds to conclusions reached in studies like that of Law, Leung, \& Wong (2004) who saw channels as supplementing each other.

Travel agents have been under stress due to direct air bookings through air carriers for some time. Evidence is now available of attempts to replace travel agents and other web based agencies for hotel accommodation bookings as well. Much of the attraction of web based booking agencies is the chance to both check availability and to comparison shop for accommodation. Hotels are attacking this through the twin strategies of best price guarantees and loyalty programs. We found the following categorization consistent with the small sample in our study.

\begin{tabular}{|l|l|l|}
\hline Use of partners & Web site component & Example \\
\hline None & Use of outsourced bookings & Kingsgate \\
\hline Some & $\begin{array}{l}\text { In house or hotel group book- } \\
\text { ings }\end{array}$ & Holiday Inn \\
\hline Aggressive & $\begin{array}{l}\text { Best price guarantees, re- } \\
\text { served space and preferential } \\
\text { treatment of member bookings }\end{array}$ & Westin \\
\hline
\end{tabular}

So far these results have shown considerable technical sophistication in our population of hotels. We also found some interesting omissions. All our sample sites provided significant information about local activities and attractions. Only one of the surveyed sites went on to provide even a static link to any of those providers. This is unusual in businesses with advanced sites. The advantage of redirection to business partners is both financial and benefits from search engine optimization. This oversight is worthy of further study.

Another interesting feature not showing up in our study is the absence of attempts to create barriers to entry. For an established organization these are traditional methods of protecting markets. In the case of our hotel study we found that all sampled organizations were relying completely on branding for their competitive edge. This approach is fraught with potential problems. One study (O’Neill \& Mattila, 2004) has found that "although larger brands and brands with higher levels of guest satisfaction have higher occupancy levels, brands with a higher percentage of franchised properties experience lower occupancies."

Another missing attribute was use of very high tech features. An example that might have been used is the travel personality categories proposed by Gretzel, Mitsche, Hwang \& Fesenmaier (2004) to capture user preferences in destination recommendation systems.

At no stage did we find anything beyond the standard "one size fits all" loyalty program.

\section{Conclusion}

It is clear from our study that it is not possible to describe all the aspects of web sites using the dimensions taken from Hashim et al. (2007). Even the cheapest and smallest hotel chains had included all the dimensions that would suggest a mature web presence. In fact some of the smaller hotels were using a web strategy that created closer relationships with clients than the large hotels chains. This outcome contrasts with even a fairly recent study of 5 star hotels (Aksu $\&$ Tarcan, 2002) that found only an increase in the number of hotels using their own name on their site. 
It is very apparent that hotels are moving towards:

- Allowing or encouraging direct purchase from the web site

- Disintermediation from agents through loyalty programs and best price guarantees

- Significant use of the latest multimedia tools to present their facilities in the best light

- Integration into a hotel group's global distribution system

Interestingly hotels have not:

- Created any alliances with other tourism providers in their area.

- Although other activities are advertised, they are not linked or facilitated in the usual site

- Discernably built barriers to entry via the Web for competitors and appear to be relying on branding

The message for business use of the web is that competitors have probably provided all the "simple" functionality that a modern business web site needs. The future must be one where the business thinks about the possibilities for alignment. Sin, Tse, Chan, Heung, \& Yim, (2006) tell us that "research points out that managers of service firms should discard old patterns of thinking and adopt new operational and strategic ways of doing business."

More research needs to investigate channel distribution strategy, including both channel distribution costs and, forecasting where future hotel bookings are likely to come from.

\section{References}

Aksu, A. A., \& Tarcan, E. (2002). The Internet and five-star hotels: A case study from the Antalya region in Turkey. International Journal of Contemporary Hospitality Management, 14 (2), 94-97.

Buhalis, D. (1998). Strategic use of information technologies in the tourism industry. Tourism Management, 19(3), 409-423.

Clarke, R. (2005). The path of development of strategic information systems theory. Retrieved Nov 13, 2007 from http://www.anu.edu.au/people/Roger.Clarke/SOS/StratISTh.html

Gilbert, D. C. (1990). European tourism product purchase methods and systems. The Service Industries Journal, 664-679.

Gretzel, N. U., Mitsche, N., Hwang, Y., \& Fesenmaier, D. R. (2004). Tell me who you are and I will tell you where to go: use of travel personalities in destination recommendation systems. Information Technology \& Tourism, 7(1), 3-12.

Hashim, N. H., Murphy, J., \& Law, R. (2007). A review of hospitality website design frameworks. Information and Communication Technologies in Tourism, 219-230.

Heichler, E. (1997). Internet lacks content for women. Computerworld, 31(19), 17.

Heung, V. C. S. (2003). Internet use by international travelers: reasons and barriers. International Journal of Contemporary Hospitality Management, 15(7), 370-378.

Jang, S. S., Hu, C., \& Bai, B. (2006). A canonical correlation analysis of e-relationship marketing and hotel financial performance. Tourism and Hospitality Research, 6 (4), 241-250.

Law, R., \& Hsu, C. H. C. (2006). Importance of hotel website dimensions and attributes: perceptions of online browsers and online purchasers. Journal of Hospitality \& Tourism Research, 30, 295.

Law, R., Leung, K. \& Wong. (2004). The impact of the Internet on travel agencies. International Journal of Contemporary Hospitality Management, 16(2), 100-107. 
Law, R., Law, Angela \& Wai, Edmund (2001). The impact of the internet on travel agencies in Hong Kong. Journal of Travel \& Tourism Marketing, Vol. 11 (2/3) .

Maurer, E. (2003). Internet for the retail travel industry. Thomson.

Melbourne City Council. (2007). [Untitled] Retrieved Oct 2007 from http://www.melbourne.vic.gov.au/info.cfm?top=269\&pg=2326

Murphy, J., Schegg, R., \& Olaru, D. (2006). Investigating the evolution of hotel Internet adoption. Information Technology \& Tourism, 8, 161-177.

O’Neill, J. W., \& Mattila, A. S. (2004). Hotel branding strategy: its relationship to guest satisfaction and room revenue. Journal of Hospitality \& Tourism Research, 28, 156.

Porter, M. (2001). Strategy and the Internet. [Product number 6538] Harvard Business School Publishing.

Sigala, M., Lockwood, Andrew \& Jones, Peter (2001). Strategic implementation and IT: gaining competitive advantage from the hotel reservations process. International Journal of Contemporary Hospitality Management. 13/7, 364-371.

Sin, L. Y. M., Tse, A. C. B., Chan, H., Heung, V. C. S., \& Yim, F. H. K. (2006). The effects of relationship marketing orientation on business performance in the hotel industry. Journal of Hospitality \& Tourism Research, 30, 407.

Tweeney, D. (1997). Making money on the web: what is really working? Infoworld, 19(36), 63-64.

Tourism Victoria. (2007). Forecast visitation to Victoria: June 2007 forecasts. Tourism Victoria, Melbourne.

Yoffie, A. J. (1997). The e-shopper. Brandweek. 38(19), 30-32.
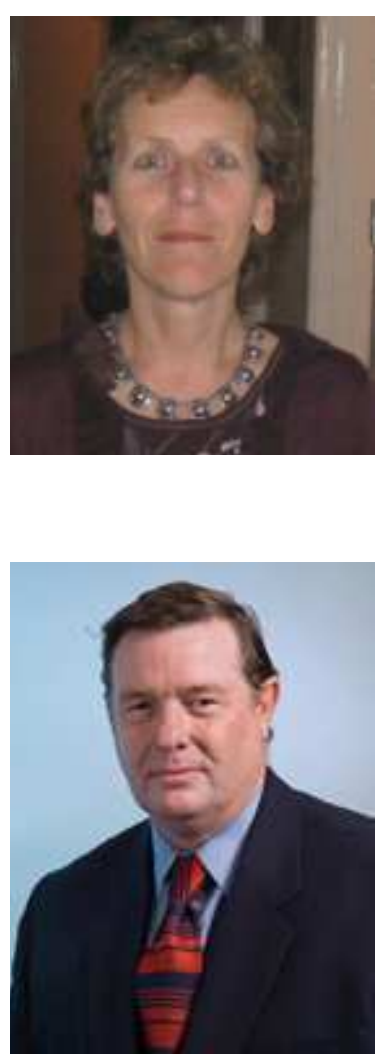

Bill Davey is a Senior Lecturer at RMIT University, Melbourne Australia in the Business Information Technology School. He is currently researching effectiveness in communications around the requirements elicitation stages of information systems development.
Audra Lukaitis is a Senior Lecturer at RMIT University, Melbourne in the Business Information Technology School where she is currently researching ICTs in Tourism \& Hospitality with a view to developing a new subject.

\section{Biography}

